\title{
ERRATUM
}

\section{Social identities and the expansion of stone bead-making in Neolithic Western Asia: new evidence from Jordan-ERRATUM}

Katherine Wright \& Andrew Garrard

Published by Cambridge University Press, 2 January 2015.

In a 2003 article by Katherine Wright and Andrew Garrard, an error occurred in the digital publication of their Table 2. It was correctly produced in print in 2003, but was incomplete when published online; it is now correctly reproduced below.

\section{Full citation}

Wright, K. \& A. Garrard 2003. Social identities and the expansion of stone bead-making in Neolithic Western Asia: new evidence from Jordan. Antiquity 77: 267-84. https://doi.org/10.1017/S0003598X00092267 


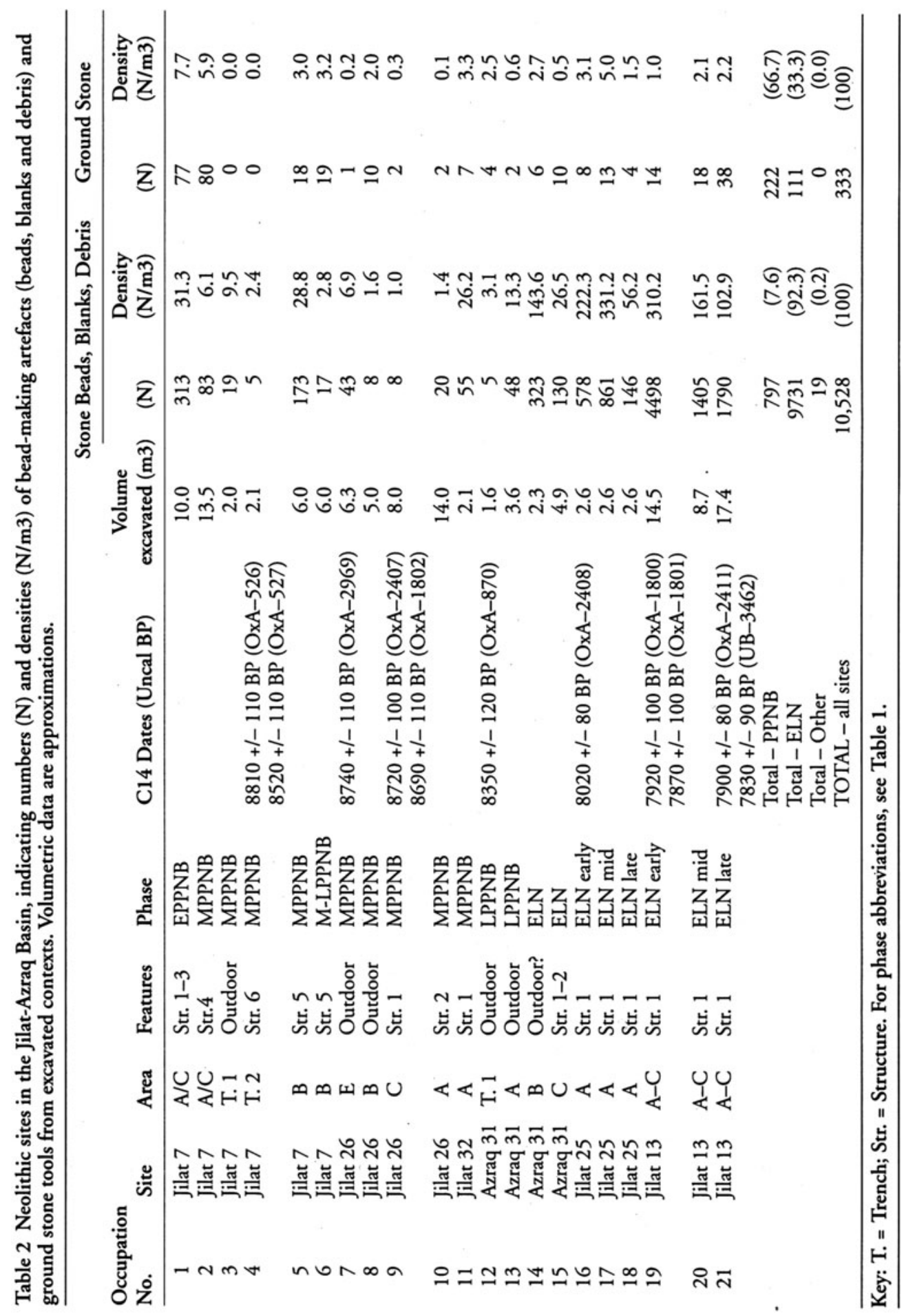

(C) Antiquity Publications Ltd, 2018 